\title{
Okul Öncesi Dönem Çocuklarının Öz Düzenleme Becerilerinin Bazı Demografik Değişkenler Açısından İncelenmesi
}

\section{Examination Of Pre-School Children's Self-Regulation Skills in Terms of Some Demographic Variables}

\author{
Seda Saraç ${ }^{1 *}$, Tuğba Abanoz ${ }^{2}$, Hülya Gülay Ogelman ${ }^{3}$ \\ ${ }^{1}$ Dr. Öğr. Üyesi, Bahçeşehir Üniversitesi, sedabiryan@gmail.com, 0000-0002-4598-4029, *Sorumlu Yazar \\ ${ }^{2}$ Dr., Bahçeşehir Koleji, tugbabaskent@gmail.com, 0000-0001-8905-4002 \\ ${ }^{3}$ Prof. Dr., Sinop Üniversitesi, ogelman@sinop.edu.tr, 0000-0002-4245-0208
}

Geliş tarihi/Received : 27.12.2020 Kabul tarihi/Accepted: 23.06.2021 Yayın tarihi/Published: 30.06.2021

\begin{abstract}
ÖZET
$\mathrm{Bu}$ çalı̧̧manın amacı, okul öncesi dönem çocukların öz düzenleme becerilerinin cinsiyet ve ebeveyn eğitim değişkenleri açısından incelenmesidir. Araştırmanın çalışma grubunu 60-72 aylık (M=63.660; SS: 10.896) 2091 çocuk oluşturmaktadır. Öz düzenlemenin tüm boyutlarında (engelleyici kontrol, dikkat ve çalışma belleği) ve toplam puan açısından kız çocuklarının puanlarının erkek çocuklardan daha yüksek olduğunu ve bu farkların tüm boyutlarda istatistiki olarak anlamlı olduğu görülmektedir. Ayrıca hem annenin hem de babanın eğitim durumu yükseldikçe çocukların tüm boyutlarının (engelleyici kontrol, dikkat ve çalışma belleği) ve toplam puanlarının yükseldiği sonucuna ulaşılmıştır. Annenin çalışıyor olmasının da çocukların öz düzenleme becerilerine olumlu katkısı olduğu, çalışan annelerin çocuklarının öz düzenleme puanlarının daha yüksek olduğu görülmüştür.
\end{abstract}

Anahtar Kelimeler: Öz düzenleme, çalışma belleği, engelleyici kontrol, dikkat, okul öncesi, ebeveyn

\begin{abstract}
The aim of this study is to examine the self-regulation skills of preschool children in terms of gender and parent education variables. The participants were 2091 children aged between 60 and 72 months ( $M=63,660$; SS: 10,896). It was found that girls' scores are higher than boys in all dimensions of self-regulation (inhibitory control, attention and working memory) and total self regulation, and these differences were statistically significant for all dimensions. In addition, it was concluded that all dimensions (inhibitory control, attention and working memory) and total self regulation scores of the children increased as the educational status of both mothers and fathers increased. Mothers' working status also contributed positively to children's self-regulation skills, and children of working mothers had higher self-regulation scores.
\end{abstract}

Keywords: Self-regulation, working memory, attention, inhibitory control, preschool, parents 


\section{GÍRIŞ}

Öz düzenleme kavramı, çocuğun sağlıklı gelişiminin önemli bir belirleyicisi olarak doğmuştur. Erken çocukluk eğitiminde, çocuklar akranlarıyla çember zamanında, sıra beklerken, oyun oynarken ve çeşitli etkinlikler aracılığıyla sosyalleşir. Bu süreçlerde çocuklar plan ve iş birliği yapma, bir konuya odaklanma, dürtülerini kontrol etme ve yönergeleri takip etmeye ihtiyaç duyarlar. Bu davranışlar, çocukların öz düzenleme becerilerine bağlıdır (McClelland \& Cameron, 2012). Yaşamın ilk yıllarında, çocukların dikkat ve davranışlarını yönetebilme becerisi, sağlıklı bir sosyal ve akademik gelişime zemin oluşturur (McCoy, 2019; McClelland \& Cameron, 2012). Öz düzenlemenin sağlıklı bir gelişimin temel yapı taşı olarak görülmeye başlamasıyla birlikte, öz düzenlemenin belirleyicilerinin neler olduğu üzerine yapılan araştırmalar da artış göstermiştir (Piotrowski, Lapierre \& Linebarger, 2013). Alan yazında öz düzenleme, belli bir amaca yönelik bilgiyi anlama, alınan kararı ve sonuçlarını değerlendirme, uygun kararlar verme olarak tanımlanmaktadır (Widiastuti, 2017; McClelland, Geldhof, Cameron \& Wanless, 2015; McClelland \& Cameron, 2012). Diğer bir tanımla; özdüzenleme bilişsel bir yetenek veya akademik bir performans değildir; daha ziyade öğrencilerin zihinsel yeteneklerini akademik becerilere dönüştürdükleri kendi kendini yönetme sürecidir (Zimmerman, 2002). Özdüzenleme becerileri, diğer beceriler gibi doğumdan itibaren yavaş yavaş gelişmeye başlar. Bu beceriler erken çocukluk döneminde çok hızlı bir gelişme gösterirler (McClelland \& Cameron, 2012). Eğitim ve gelişim psikolojisi alanında yapılan araştırmalar, çocukların okula başlamadan önce temel öz düzenleme kapasitelerini geliştirdiklerine dair sonuçlar ortaya koymuştur (Perry, 2019). Çocuklar ilk önce beden ve davranışlarını, daha sonra zamanla duygularını kontrol etmeyi öğrenirler (Bodrova \& Leong, 2007). Küçük çocuklar için dürtüsel davranışı kontrol etmeyi öğrenmek en önemli ihtiyaçtır (Bodrova \& Leong, 2005). Erken çocuklukta özdüzenleme uzun dönem gelişim ve sağllk durumunun önemli bir göstergesidir (Clausse, Robinson, Kawinski, Charania, Holbrook, So, Ghandour, Smith, Satterfield-Nash, Peacock \& Boyle, 2020). Özdüzenleme çok bileşenli bir yapıdır. İçinde davranışsal, bilişsel ve duygusal düzenlemelerden oluşan tamamlayıcı bir kavramdır. Davranışsal düzenleme, dikkat odaklama, çalışma belleği ve engelleyici kontrol gibi yürütücü işlev becerilerini ifade eder (Astarlar, 2019).

Çalışma belleği; bilgileri kısa süreli muhafaza etme ve kullanma becerisidir (Baddeley \& Hitch, 1974). Çalışma belleğinin temel özelliği, bilgiyi akılda tutma ve düşünme ve davranışa rehberlik etmek için etkin bir şekilde kullanma gerekliliğidir (Bailey \& Hitch, 1974; Best \& Miller, 2010; akt. Bailey \& Jones, 2019). Diğer bir deyişle çalışma belleği, bir görevi tamamlamak için gerekli olan yönergeleri akılda tutarken aynı zamanda o görevi yapmamızı sağlar. Öğretmen çocuğa, ellerini yıkadıktan sonra dolabından hikâye kitabını alıp getirmesini istediğinde, çocuğun hem yönergeleri hem de sırasını aklında tutup, buna uygun davranabilmesi için çalışma belleği gerekir (Saraç \& Güleç, 2019).

Engelleyici kontrol; davranışların düzenlenmesi olarak da adlandırılan engelleyici kontrol, bireyin amacına ulaşabilmesi için dürtüsünü bastırmasıdır (Cuevas, Rajan \& Bryant, 2018). Öğretmenin sorduğu soruya cevap verebilmek için parmak kaldırıp beklemesi, yemek istediği çikolatayı yemekten sonra yiyebileceği söylenen çocuğun bekleyip yememesi vb. davranışlar engelleyici kontrol sayesinde başarılabilmektedir (Saraç \& Güleç, 2019).

Dikkat; yönetici dikkat, farkındalığımızın ayrıntılarını kontrol etmek için kullanılır ve bu nedenle iradeyle yakından ilgilidir. Deneyimler, yönetici dikkate dahil olan bütünleştirilmiş sinir alanı ağı önermektedir. Bu ağ; seçim yapma, hatayı düzeltme ve duyguları düzenleme konusunda gönüllü olarak sergilediğimiz (istemli) becerilerimizle ilişkilidir (Posner \& Rothbart, 1998). Bilişsel esneklik ise dikkatin esnekliğini ifade etmektedir. Örneğin; sınıf içerisinde çocuğun hem bir süre grup etkinliklerine dikkatini vermesi ve bu dikkati sürdürmesi, 
hem de öğretmenin yönergesine uyarak grup etkinliğini bırakarak başka bir etkinliğe (yemek, bahçe vb.) geçebilmesi bilişsel esnekliğin göstergeleridir (Saraç \& Güleç, 2019).

Okul öncesi dönem çocuklarının öz düzenleme becerileri, tüm kültürlerde çocuğun ileriki akademik başarısının ve sosyal uyumunun belirleyicisi olarak kabul edilmektedir. Bu nedenle davranışsal öz düzenleme becerilerini destekleyen veya engelleyen faktörlerin belirlenmesi çok önemlidir. Bu amaçla bu faktörleri belirlemeye yönelik pek çok araştırma yapılmaktadır. Storksen, Ellingsen, Wanless \& McClelland'ın (2014) cinsiyet ve sosyoekonomik düzeyin çocukların öz düzenleme becerileri üzerindeki etkilerini belirlemeye yönelik yaptıkları araştırmada, davranışsal düzenleme konusunda kızların erkeklerden daha iyi performans sergiledikleri, ailelerin sosyoekonomik seviyelerinin kızların öz düzenleme davranışları üzerinde olumlu bir etkiye sahip olduğunu ancak erkeklerde bir etkisi olmadığı ortaya konulmuştur. Benzer şekilde 2016 yılında ebeveynlerden alınan bilgiler doğrultusunda gerçekleştirilen araştırmada, sosyoekonomik düzeyi yüksek aileler, çocuklarının öz düzenleme becerisinin gelişmiş olduğunu ifade etmişlerdir (Claussen, vd., 2020). İnsan yaşamının ilk yıllarında edinilmesi önemli olan öz düzenleme; duygu, düşünce ve davranışları kontrol etme becerileri olarak tanımlanırken, ebeveynlerin çocuğa karşı izin verici tutumu da bu becerileri destekleyen faktörlerdendir (Eke, 2017).

Çocuğun ilk öğrenme çevresi ailesidir. Bu nedenle anne ve babalar çocuğa rol model olarak, dönütler vererek çocuğun öz düzenleme becerilerini destekleyebilir (Astarlar, 2019). Yapılan çalışmalar incelendiğinde anne baba eğitim durumu ve anne çalışma durumuna yönelik araştırma sayısının oldukça sınırlı olduğu görülmüştür. Bu amaç doğrultusunda bu araştırmada üst sosyoekonomik düzey ailelerden gelen 5-6 yaş grubu çocukların öz düzenleme becerilerinin çeşitli demografik değişkenler açısından incelenmesi amaçlanmıştır. Bu amaç doğrultusunda aşağıdaki sorulara yanıt aranmıştır:

1. 5-6 yaş grubu çocukların öz düzenleme becerileri (engelleyici kontrol, dikkat, çalş̧ma belleği) cinsiyete göre farklılık göstermekte midir?

2. 5-6 yaş grubu çocukların öz düzenleme becerileri (engelleyici kontrol, dikkat, çalışma belleği) çocukların anne eğitim durumuna göre farklılık göstermekte midir?

3. 5-6 yaş grubu çocukların öz düzenleme becerileri (engelleyici kontrol, dikkat, çalışma belleği) çocukların baba eğitim durumuna göre farklllık göstermekte midir?

4. 5-6 yaş grubu çocukların öz düzenleme becerileri (engelleyici kontrol, dikkat, çalışma belleği) çocukların anne çalışma durumuna göre farklılık göstermekte midir?

\section{YÖNTEM}

\section{Araştırmanın Modeli}

Bu araştırmada okul öncesi dönem 5-6 yaş grubu çocuklarının özdüzenleme becerilerinin çeşitli demografik değişkenlerle ilişkisi değerlendirilmiştir. Bu nedenle araştırmanın modeli ilişkisel tarama modelidir.

\section{Çalışma Grubu}

$\mathrm{Bu}$ araştırmanın çalışma grubunu 10 farklı şehirde (Samsun, İzmir, İstanbul, Gaziantep, Eskişehir, Diyarbakır, Bursa, Aydın, Antalya, Ankara) özel okul öncesi kurumlara devam eden 60-72 aylık (M= 63.660; SS: 10.896) 2091 çocuk oluşturmaktadır. Çocukların 1048'sı kız (\%50.1) 1043'sı erkektir (\%49.9). Çocukların tamamı yüksek SED ailelerden gelen ve normal gelişim özellikleri gösteren çocuklardır. Babaların tamamı (\%100) çalışmaktadır. Katılımcılara ilişkin demografik bilgiler Tablo 1'de yer almaktadır. 
Tablo 1. Katılımcilara ait Demografik Bilgiler

\begin{tabular}{llcc}
\hline & Özellikler & $F$ & $\%$ \\
\hline \multirow{2}{*}{$\begin{array}{l}\text { Çocukların } \\
\text { Cinsiyeti }\end{array}$} & Kız & 1048 & 50.1 \\
\cline { 2 - 4 } $\begin{array}{l}\text { Anne eğitim } \\
\text { durumu }\end{array}$ & Erkek & 1043 & 49.9 \\
\cline { 2 - 4 } & Lise & 166 & 7.9 \\
\cline { 2 - 4 } & Lisans & 1731 & 82.8 \\
\hline \multirow{2}{*}{$\begin{array}{l}\text { Baba eğitim } \\
\text { durumu }\end{array}$} & Lise & 194 & 9.3 \\
\cline { 2 - 4 } & Lisans & 132 & 6.3 \\
\cline { 2 - 4 } & Lisansüstü & 208 & 93.7 \\
\hline $\begin{array}{l}\text { Anne çalışma } \\
\text { durumu }\end{array}$ & Çalışıyor & 1397 & 66.8 \\
\cline { 2 - 4 } & Çalışmıyor & 694 & 33.2 \\
\hline
\end{tabular}

\section{Veri Toplama Araçları}

\section{Demografik Bilgi Toplama Formu}

Araştırmacılar tarafından hazırlanan kişisel bilgiler formu, her bir çocuk için öğretmenler tarafından doldurulmuştur. Formda çocukların cinsiyeti, doğum tarihi, anne eğitim durumu, baba eğitim durumu, baba çalışma durumu ve anne çalışma durumuna ilişkin sorular bulunmaktadir.

\section{4-6 Yaş Çocuklarına Yönelik Öz Düzenleme Becerileri Ölçeği (Öğretmen Formu)}

Çocukların öz düzenleme becerilerini ölçmek amacıyla İvrendi ve Erol (2018) tarafından geliştirilen 4-6 Yaş Çocuklarına Yönelik Öz Düzenleme Becerileri Ölçeği (Öğretmen Formu) kullanılmıştır. Ölçme aracı 22 maddeden oluşmaktadır. Ölçeğin dikkat (9 madde), engelleyici kontrol ( 8 madde) ve çalışma belleği (5 madde) olmak üzere 3 alt boyutu bulunmaktadır. Ölçek, öğretmenlerden tarafindan sınıflarındaki normal gelişim gösteren çocukların her biri için doldurulmuştur. Öğretmenler, çocukları 5'li likert üzerinden değerlendirmektedir (1= Hiçbir zaman, 5= Her zaman). Orijinal çalışmada ölçeğin tümü için Cronbach Alpha katsayısı .94 olarak bulunmuştur. Dikkat alt ölçeği için .91, Engelleyici Kontrol alt ölçeği için .91, Çalışma Belleği alt ölçeği için ise .87 olarak hesaplanmıştır. Bu çalışmada ise toplam ölçek için .95 , alt ölçekler için ise sırasıyla .94, .92 ve .92 olarak hesaplanmıştır.

\section{Verilerin Toplanması}

Veri toplamaya sürecinden önce öz düzenlemeye yönelik ölçme aracı ile ilgili gerekli izinler alınmıştır. Çalışma grubu belirlendikten sonra, okullarda görev yapan öğretmenlerle görüşmeler gerçekleştirilmiştir. Okul öncesi öğretmenleri her bir çocuk için ölçekleri doldurmuştur. Öğretmenler, çocukları en az 4 aydır tanımaktadırlar.

\section{Verilerin Analizi}

Araştırma verilerinin analizi için SPSS 21.0 paket programı kullanılmıştır. Veriler normal dağılım gösterdiğinden, cinsiyet ve annenin çalışma durumuna göre çocukların öz düzenleme puanlarının farklılaşıp farklılaşmadığının incelenmesi için Bağımsız Örneklemler t Testi analizleri yapılmıştır. Anne ve baba eğitim durumlarına göre puanların farklılaşıp farklılaşmadığını incelemek amacıyla ise Tek Yönlü ANOVA analizleri yapılmıştır. 


\section{BULGULAR VE TARTIŞMA}

Tablo 2. Çocukların Öz düzenleme Puanlarının Cinsiyete göre Bağımsız Gruplar T-Testi Sonuçları

\begin{tabular}{|c|c|c|c|c|}
\hline & & Ortalama & $\mathrm{SS}$ & $\mathrm{t}(2089)$ \\
\hline \multirow{2}{*}{$\begin{array}{l}\text { Engelleyici } \\
\text { Kontrol }\end{array}$} & $\mathrm{K} 1 \mathrm{Z}$ & 34.635 & 4.891 & \multirow[t]{2}{*}{$4.858^{*}$} \\
\hline & Erkek & 33.527 & 5.513 & \\
\hline \multirow[t]{2}{*}{ Dikkat } & $\mathrm{K} 1 \mathrm{z}$ & 39.525 & 5.378 & \multirow[t]{2}{*}{$9.326^{*}$} \\
\hline & Erkek & 37.044 & 6.715 & \\
\hline \multirow[t]{2}{*}{ Çalışma Belleği } & $\mathrm{K} 1 \mathrm{z}$ & 23.140 & 2.554 & \multirow[t]{2}{*}{$6.141 *$} \\
\hline & Erkek & 22.373 & 3.125 & \\
\hline \multirow{2}{*}{$\begin{array}{l}\text { Özdüzenleme } \\
\text { Toplam }\end{array}$} & $\mathrm{K} 1 \mathrm{Z}$ & 97.300 & 11.018 & \multirow[t]{2}{*}{$8.052 *$} \\
\hline & Erkek & 92.945 & 13.583 & \\
\hline
\end{tabular}

$* \mathrm{p}<.001$

Tablo 2'ye göre öz düzenlemenin tüm boyutlarında (engelleyici kontrol, dikkat ve çalışma belleği) ve toplam puan açısından kız çocuklarının puanlarının erkek çocuklardan daha yüksek olduğunu ve bu farkların tüm düzeylerde boyutlarda istatistiki olarak anlamlı olduğunu göstermektedir $(\mathrm{p}<.001)$.

Tablo 3. Çocukların Öz düzenleme Becerilerinin Anne Eğitim Durumlarına göre Tek Yönlü ANOVA Sonuçları

\begin{tabular}{|c|c|c|c|c|}
\hline & & Ortalama & SS & $\mathrm{F}$ \\
\hline \multirow[t]{3}{*}{ Engelleyici Kontrol } & Lise mezunu & 32.313 & 6.271 & \multirow[t]{3}{*}{$13.258^{*}$} \\
\hline & Lisans mezunu & 34.140 & 5.122 & \\
\hline & Lisansüstü mezunu & 35.083 & 4.962 & \\
\hline \multirow[t]{3}{*}{ Dikkat } & Lise mezunu & 36.458 & 7.361 & \multirow[t]{3}{*}{$9.673 *$} \\
\hline & Lisans mezunu & 38.356 & 5.812 & \\
\hline & Lisansüstü mezunu & 38.287 & 6.206 & \\
\hline \multirow[t]{3}{*}{ Çalışma Belleği } & Lise mezunu & 21.928 & 3.449 & \multirow[t]{3}{*}{$8.817 *$} \\
\hline & Lisans mezunu & 22.795 & 2.805 & \\
\hline & Lisansüstü mezunu & 23.139 & 2.871 & \\
\hline \multirow{3}{*}{$\begin{array}{l}\text { Öz Düzenleme } \\
\text { Toplam }\end{array}$} & Lise mezunu & 90.699 & 15.313 & \multirow[t]{3}{*}{$13.999 *$} \\
\hline & Lisans mezunu & 95.291 & 12.218 & \\
\hline & Lisansüstü mezunu & 97.459 & 12.033 & \\
\hline
\end{tabular}

$* \mathrm{p}<.001$

Tablo 3 doğrultusunda annenin eğitim durumu yükseldikçe çocukların engelleyici kontrol, dikkat, çalışma belleği ve toplam öz düzenleme puanları yükseldiği görülmektedir. Farkların tam olarak hangi gruplar arasında olduğunu belirlemek için Tukey HSD testleri yapılmıştır. Anneleri lise mezunu olan çocukların engelleyici kontrol puanları hem lisans mezunu annelerin çocuklarından $(\mathrm{p}<.001)$ hem de lisansüstü mezunu annelerin çocuklarından $(\mathrm{p}<.001)$ düşüktür. Anneleri lisans mezunu olan çocukların engelleyici kontrol puanları da lisansüstü mezunu olan annelerin çocuklarının puanlarından düşüktür $(\mathrm{p}<.05)$. Anneleri lise mezunu olan çocukların dikkat puanları hem lisans mezunu annelerin çocuklarından $(\mathrm{p}<.001)$ hem de lisansüstü mezunu annelerin çocuklarından $(\mathrm{p}<.001)$ düşüktür. Ancak, anneleri lisans mezunu 
olan çocukların ile anneleri lisansüstü mezunu olan çocukların dikkat puanları arasındaki fark istatistiki olarak anlamlı değildir $(\mathrm{p}=.144)$. Anneleri lise mezunu olan çocukların çalışma belleği puanları hem lisans mezunu annelerin çocuklarından $(p<.001)$ hem de lisansüstü mezunu annelerin çocuklarından $(\mathrm{p}<.001)$ düşüktür. Ancak, anneleri lisans mezunu olan çocukların ile anneleri lisansüstü mezunu olan çocukların çalışma belleği puanları arasındaki fark istatistiki olarak anlamlı değildir $(\mathrm{p}=.252)$. Toplam öz düzenleme puanları karşılaştırıldığında ise anneleri lise mezunu olan çocukların toplam öz düzenleme puanlarının hem lisans mezunu annelerin çocuklarından $(\mathrm{p}<.001)$ hem de lisansüstü mezunu annelerin çocuklarından $(\mathrm{p}<.001)$ düşük olduğu ancak anneleri lisans ve lisansüstü mezunu olan çocukların toplam öz düzenleme puanları arasındaki fark istatistiki olarak anlamlı olmadığı görülmektedir $(\mathrm{p}=.057)$.

Tablo 4. Çocukların Öz düzenleme Düzeylerinin Anne Çalışma Durumuna Göre Bağımsız Örneklemler t Testi

\begin{tabular}{lllll}
\hline & & Ortalama & SS & \multirow{2}{*}{ t (2089) } \\
\hline Engelleyici & Çalışıyor & 34.520 & 5.034 & \multirow{2}{*}{$5.454^{*}$} \\
\cline { 2 - 4 } Kontrol & Çalışmıyor & 33.202 & 5.528 & \\
\hline Dikkat & Çalışıyor & 38.642 & 6.128 & \multirow{2}{*}{$3.704^{*}$} \\
& Çalışmıyor & 37.576 & 6.303 & \\
\hline Çalışma Belleği & Çalışıyor & 22.956 & 2.770 & \multirow{2}{*}{$4.334^{*}$} \\
\cline { 2 - 4 } & Çalışmıyor & 22.360 & 3.047 & \\
\hline Öz Düzenleme & Çalışıyor & 96.116 & 12.120 & \multirow{2}{*}{$4.999^{*}$} \\
Toplam & Çalışmıyor & 93.138 & 13.163 & \\
\hline
\end{tabular}

$* \mathrm{p}<.001$

Tablo 4 incelendiğinde, annesi çalışan çocukların hem toplam öz düzenleme puanları hem de alt boyutlara ait puanları annesi çalışmayan çocuklardan daha yüksek olduğu ve aradaki farkın istatistiki olarak anlamlı olduğu görülmektedir $(\mathrm{p}<.001)$.

Tablo 5. Çocukların Öz düzenleme Becerilerinin Baba Eğitim Durumlarına Göre Tek Yönlü ANOVA Sonuçları

\begin{tabular}{|c|c|c|c|c|}
\hline & & Ortalama & SS & $F$ \\
\hline \multirow{3}{*}{$\begin{array}{l}\text { Engelleyici } \\
\text { Kontrol }\end{array}$} & Lise mezunu & 32.599 & 6.207 & \multirow[t]{3}{*}{$10.449 *$} \\
\hline & Lisans mezunu & 34.057 & 5.188 & \\
\hline & Lisansüstü mezunu & 35.236 & 4.728 & \\
\hline \multirow[t]{3}{*}{ Dikkat } & Lise mezunu & 36.371 & 7.268 & \multirow[t]{3}{*}{$10.584^{*}$} \\
\hline & Lisans mezunu & 38.284 & 6.159 & \\
\hline & Lisansüstü mezunu & 38.287 & 5.548 & \\
\hline \multirow{3}{*}{$\begin{array}{l}\text { Çalışma } \\
\text { Belleği }\end{array}$} & Lise mezunu & 21.955 & 3.481 & \multirow[t]{3}{*}{$7.948^{*}$} \\
\hline & Lisans mezunu & 22.763 & 2.840 & \\
\hline & Lisansüstü mezunu & 23.226 & 2.669 & \\
\hline \multirow{3}{*}{$\begin{array}{l}\text { Öz düzenleme } \\
\text { Toplam }\end{array}$} & Lise mezunu & 90.924 & 15.913 & \multirow[t]{3}{*}{$12.981 *$} \\
\hline & Lisans mezunu & 95.104 & 12.391 & \\
\hline & Lisansüstü mezunu & 97.995 & 11.503 & \\
\hline
\end{tabular}

$* \mathrm{p}<.001$

Tablo 5 incelendiğinde, babanın eğitim durumu yükseldikçe çocukların engelleyici kontrol, dikkat, çalışma belleği ve toplam öz düzenleme puanları yükseldiği göstermektedir. Farkların tam olarak hangi gruplar arasında olduğunu belirlemek amacıyla yapılan Tukey HSD sonuçlarına göre babaları lise mezunu olan çocukların engelleyici kontrol puanları hem lisans mezunu babaların çocuklarından $(\mathrm{p}<.001)$ hem de lisansüstü mezunu babaların çocuklarından 
$(\mathrm{p}<.001)$ düşüktür. Babaları lisans mezunu olan çocukların engelleyici kontrol puanları da lisansüstü mezunu olan babaların çocuklarının puanlarından düşüktür $(\mathrm{p}<.001)$. Babaları lise mezunu olan çocukların dikkat puanları karşılaştırıldığında lise mezunu babaların çocuklarının puanları hem lisans mezunu babaların çocuklarından $(\mathrm{p}<.001)$ hem de lisansüstü mezunu babaların çocuklarından $(\mathrm{p}<.001)$ düşüktür. Babaları lisans mezunu olan çocukların puanları da babaları lisansüstü mezunu olan çocukların puanlarından düşüktür $(\mathrm{p}<.05)$. Babaları lise mezunu olan çocukların çalışma belleği puanları hem lisans mezunu babaların $(p<.001)$ hem de lisansüstü mezunu babaların çocuklarından $(\mathrm{p}<.001)$ düşüktür. Ancak, lisans mezunu babaların çocuklarının dikkat puanları ile babaları lisansüstü mezunu olan çocukların çalışma belleği puanları arasındaki fark istatistiki olarak anlamlı değildir $(\mathrm{p}=.071)$. Toplam öz düzenleme puanları açısından bakıldığında ise lise mezunu babaların çocuklarının puanları, lisans $(\mathrm{p}<.001)$ ve lisansüstü $(\mathrm{p}<.001)$ mezunu babaların çocuklarından istatistiki olarak anlamlı bir şekilde düşüktür. Benzer şekilde lisans mezunu babaların çocuklarının puanları da lisansüstü mezunu babaların çocuklarından istatistiki olarak anlamlı bir şekilde düşük olduğu görülmektedir $(\mathrm{p}<.001)$.

Okul öncesi dönem çocuklarının öz düzenleme becerilerinin bazı demografik değişkenler açısından incelendiği araştırmanın sonuçlarına bakıldığında, çocukların öz düzenleme becerileri tüm boyutlarda (kontrol, dikkat ve çalışma belleği) ve toplam puan açısından kız çocuklarının puanlarının erkek çocuklardan daha yüksek olduğu ve bu farkın tüm düzeylerde anlamlı olduğu bulunmuştur. Veijalainen, Reunama \& Heikkila (2019) tarafindan, erken çocukluk eğitimine devam eden çocukların duygusal ifadelerinin gözlenmesi ve öğretmen beyanına dayalı öz düzenleme becerilerinin cinsiyet değişkenine göre incelenmesi amaciyla gerçekleştirilen çalışmada; kız çocuklarının daha fazla mutluluk, şaka ve memnuniyet içeren duygusal ifadeler kullandıkları, kız çocuklarının öz düzenleme becerilerinin erkeklerden daha yüksek olduğu ortaya konmuştur. Diğer taraftan Lenes, Gonzales, Storksen \& McClelland'in (2020) anne eğitim durumu ve cinsiyet değişkenlerinin çocukların özdüzenleme becerileri üzerindeki etkisini belirlemek amacıyla gerçekleştirdikleri araştırmada Norveç ve ABD örnekleri üzerinde çalışılmıştır. Araştırma sonunda, Norveçli kız çocuklarının öz düzenleme becerileri puanlarının erkeklerden daha yüksek olduğu, ancak ABD örneğinde böyle bir farklılığa rastlanmadığı belirtilmiştir. Bu araştırmanın cinsiyet faktörüne ilişkin bulgusunu destekleyen çalışmalar yanında (Astarlar, 2019; Daggul \& Gürşımsek, 2019; Tuzcuoğlu, Efe Azkeskin, İlçi Küsmüş \& Cengiz, 2019; Tozduman Yaralı \& Güngör Aytar, 2017; Raffaelli, Crockett \& Shen, 2005), cinsiyet ile özdüzenleme becerileri arasında ilişki olmadığını gösteren çalışmalar da bulunmaktadır. Almeqdad, Al-Hamouri, Zghoul, Al-Rousan ve Whitebread (2016) tarafindan yapılan araştırmada, Ürdünlü okul öncesi çocukların özdüzenleyerek öğrenme becerisi cinsiyet ve ebeveynlerin eğitim durumu değişkenleri açısından incelenmiştir. Araştırma sonucunda eğitim düzeyi yüksek ailelerden gelen çocukların özdüzenleyerek öğrenme düzeylerinin yüksek olduğu, cinsiyet açısından ise istatistiksel olarak anlamlı bir farklılık olmadığı bulunmuştur. Ural, Gültekin Akduman ve Şepitci Sarıbaş (2020)'ın bazı demografik özelliklerin okul öncesi eğitimi alan çocukların özdüzenleme becerileri üzerindeki etkisini incelemek amacıyla yaptıkları araştırmada, cinsiyet değişkeninin öz düzenleme becerileri üzerinde bir fark yaratmadığı sonucuna ulaşılmıştır.

Çocukların öz düzenleme becerileri anne eğitimi durumuna göre incelendiğinde, annenin eğitim durumu yükseldikçe, çocukların engelleyici kontrol, dikkat, çalışma belleği ve toplam öz düzenleme puanlarının yükseldiği bulunmuştur. Anneleri lise mezunu olan çocukların engelleyici kontrol puanları hem lisans mezunu annelerin çocuklarından hem de lisansüstü mezunu annelerin çocuklarından düşüktür. Anneleri lisans mezunu olan çocukların engelleyici kontrol puanları da lisansüstü mezunu olan annelerin çocuklarının puanlarından düşüktür. Anneleri lise mezunu olan çocukların dikkat puanları hem lisans mezunu annelerin 
çocuklarından hem de lisansüstü mezunu annelerin çocuklarından düşüktür. Ancak, anneleri lisans mezunu olan çocuklar ile anneleri lisansüstü mezunu olan çocukların dikkat puanları arasındaki fark istatistiki olarak anlamlı değildir. Anneleri lise mezunu olan çocukların çalışma belleği puanları hem lisans mezunu annelerin çocuklarından hem de lisansüstü mezunu annelerin çocuklarından düşüktür. Ancak, anneleri lisans mezunu olan çocukların ile anneleri lisansüstü mezunu olan çocukların çalışma belleği puanları arasındaki fark istatistiki olarak anlamlı değildir. Toplam puanlara bakıldığında ise; anneleri lise mezunu olan çocukların toplam öz düzenleme puanlarının hem lisans mezunu annelerin çocuklarından hem de lisansüstü mezunu annelerin çocuklarından düşük olduğu ancak anneleri lisans ve lisansüstü mezunu olan çocukların toplam öz düzenleme puanları arasındaki fark istatistiki olarak anlamlı olmadığ1 görülmektedir. Lenes, Gonzales, Storksen ve McClelland'in (2020) anne eğitim durumu ve cinsiyet değişkenlerinin çocukların özdüzenleme becerileri üzerindeki etkisini belirlemek amacıyla gerçekleştirdikleri araştırmada Norveç ve ABD örnekleri üzerinde çalışılmıştır. Araştırma sonucunda, ABD örneğinde annenin eğitim durumunun çocukların öz düzenleme becerileri üzerinde etkili olduğu ancak Norveç örneğinde istatistiksel olarak anlamlı bir farklılık olmadığı bulunmuştur. Diğer taraftan Ural, Gültekin Akduman ve Şepitci Sarıbaş (2020)'ın okul öncesi dönem çocuklarının öz düzenleme becerilerini bazı demografik değişkenlere göre inceledikleri araştırmada da benzer sonuca ulaşılmıştır. Lisans mezunu annelerin çocuklarının öz düzenleme toplam puan ortalamaları, öğrenim durumu daha düşük anneye sahip çocukların puan ortalamalarından yüksektir. Bununla birlikte öz düzenleme becerileri üzerinde anne eğitim durumunun etkisinin olmadı̆̆ını ortaya koyan çalışmalara da rastlanmıştır. Tuzcuoğlu vd., (2019) tarafından yapılan çalışmada, çocukların öz düzenleme becerisi puan ortalamaları anne öğrenim durumu değişkenine göre anlamlı bir farklılık göstermediği bulunmuştur. Piotrowski, Lapierre \& Linebarger (2012)'ın yaptığ 1 araştırmada evin eğitim ortamının değil, daha çok evin ekonomik ikliminin çocukların öz düzenlemesi ile ilişkili olduğu sonucuna ulaşılmıştır.

Çocukların öz düzenleme becerilerinin babalarının eğitim durumlarına göre farklılaşıp farklılaşmadığı incelendiğinde ise; babanın eğitim durumu yükseldikçe çocukların engelleyici kontrol, dikkat, çalışma belleği ve toplam öz düzenleme puanları yükseldiği sonucuna ulaşılmıştır. Babası lise mezunu olan çocukların engelleyici kontrol puanları hem lisans mezunu babaların çocuklarından hem de lisansüstü mezunu babaların çocuklarından düşüktür. Babaları lisans mezunu olan çocukların engelleyici kontrol puanları da lisansüstü mezunu olan babaların çocuklarının puanlarından düşüktür. Lise mezunu babaların çocuklarının puanları hem lisans mezunu babaların çocuklarından hem de lisansüstü mezunu babaların çocuklarından düşüktür. Babaları lisans mezunu olan çocukların puanları da babaları lisansüstü mezunu olan çocukların puanlarından düşüktür. Babaları lise mezunu olan çocukların çalışma belleği puanları hem lisans mezunu babaların hem de lisansüstü mezunu babaların çocuklarından düşüktür. Ancak, lisans mezunu babaların çocuklarının dikkat puanları ile babaları lisansüstü mezunu olan çocukların çalışma belleği puanları arasındaki fark istatistiki olarak anlamlı değildir. Toplam öz düzenleme puanları açısından bakıldığında ise lise mezunu babaların çocuklarının puanları, lisans ve lisansüstü mezunu babaların çocuklarından istatistiki olarak anlamlı bir şekilde düşüktür. Benzer şekilde lisans mezunu babaların çocuklarının puanları da lisansüstü mezunu babaların çocuklarından istatistiki olarak anlamlı bir şekilde düşük olduğu görülmektedir. Ural vd. (2020)'nin bazı demografik özelliklerin okul öncesi eğitimi alan çocukların öz düzenleme becerileri üzerindeki etkisini incelemek amacıyla yaptıkları araştırmada, benzer sonuçlara ulaşılmıştır. Araştırmada babaların öğrenim durumunun çocukların öz düzenleme becerileri üzerinde anlamlı bir farklılığa yol açtığı belirlenmiştir. Lisans mezunu babaların çocuklarının öz düzenleme becerileri toplam puanların, daha düşük öğrenim seviyesinde babaya sahip çocukların puan ortalamalarından daha yüksek olduğu saptanmıştır. Bununla birlikte öz düzenleme becerileri üzerinde baba eğitim durumunun etkisinin olmadığını ortaya koyan 
çalışmalara da rastlanmıştır. Tuzcuoğlu vd. (2019) tarafından yapılan çalışmada, çocukların öz düzenleme becerisi puan ortalamaları baba öğrenim durumu değişkenine göre anlamlı bir farkl1lık göstermediği bulunmuştur.

Çalışma bulguları incelendiğinde, ailenin eğitim düzeyinin çocukların öz düzenleme becerileri üzerinde etkisi olduğu söylenebilir. Bu noktada, eğitim düzeyi yükseldikçe ebeveynlerin çocuk gelişimi ve eğitimi konusunda daha fazla araştırma yaptıkları, daha fazla bilgiye sahip oldukları ve bu doğrultuda çocuklarının öz düzenleme becerilerini destekledikleri düşünülmektedir. Diğer taraftan bu araştırmada cinsiyetin öz düzenleme becerileri üzerinde etkisi olduğu sonucuna ulaşılmıştır. Ancak farklı ülkelerde gerçekleştirilen araştırma sonuçlarında cinsiyetin öz düzenleme becerileri üzerinde bir farklılık yaratmadığı ortaya konmuştur (Lenes, Gonzales, Storksen \& McClelland, 2020). Farklı sonuçlara ulaşılması, kültürler arası farklılığın bu duruma sebep olabileceğini düşündürmektedir. Bu açıdan, cinsiyetin öz düzenleme becerileri üzerindeki etkisini geniş çaplı bir çalı̧̧ma grubuyla ortaya koymak amacıyla ülkeler arası karşılaştırmaların yapılabileceği çalışmalara ihtiyaç duyulmaktadır. Anne çalışma durumunun da çocukların öz düzenleme becerileri üzerinde etkili olduğu söylenebilir. Çalışan annelerin çocuklarını çeşitli yönergeler aracılığıyla, sorumluluklar vererek öz düzenleme becerilerini destekledikleri düşünülebilir.

Annenin lisans veya lisansüstü mezunu olması çocukların dikkat, çalışma belleği ve toplam puanları üzerinde bir farklılık yaratmadığı bulunmuştur. Diğer taraftan, öz düzenleme becerileri üzerinde anne-babaların eğitim durumlarının etkisine ilişkin sonuçlar değerlendirildiğinde, öz düzenleme becerilerinden dikkat alt boyutunda hem anne hem de babaların lisans ve lisansüstü mezunu olmalarının bir farklılık yaratmadığı sonucuna ulaşılmıştır. Eğitim durumunun öz düzenleme becerilerini etkileme noktasında kritik eşiğin lise ve üstü eğitime sahip olup olmama durumu olduğu düşünülebilir.

\section{SONUÇ VE ÖNERILER}

Öz düzenlemenin tüm boyutlarında (engelleyici kontrol, dikkat ve çalışma belleği) ve toplam puan açısından kız çocuklarının puanlarının erkek çocuklardan daha yüksek olduğunu ve bu farkların tüm boyutlarda istatistiki olarak anlamlı olduğu görülmektedir. Ayrıca hem annenin hem de babanın eğitim durumu yükseldikçe çocukların tüm boyutlarının (engelleyici kontrol, dikkat ve çalışma belleği) ve toplam puanlarının yükseldiği sonucuna ulaşılmıştır. Annenin çalışıyor olmasının da çocukların öz düzenleme becerilerine olumlu katkısı olduğu, çalışan annelerin çocuklarının öz düzenleme puanlarının daha yüksek olduğu görülmüştür.

Araştırmanın bulguları doğrultusunda, Türkiye'de okul öncesi dönem çocuklarının öz düzenleme becerilerine ilişkin çalışmalar arttırılmalıdır. Böylece küçük çocukların öz düzenleme becerilerinde etkili olan değişkenler çok yönlü incelenebilecektir. Anne-babaların eğitim düzeylerinin arttırılması, çocukların öz düzenleme başta olmak üzere tüm gelişim alanlarını desteklemek açısından da önem taşımaktadır. Bununla birlikte okul öncesi eğitim kurumlarında, anne-babalara düzenli olarak çocukların öz düzenleme ve diğer becerilerini nasıl destekleyebilecekleri ile ilgili eğitimler verilmeli, evde etkinlikler yapmaları sağlanmalıdır. Boylamsal çalışmalar ile çocukların öz düzenleme becerileri uzun süreli olarak izlenmelidir. 


\section{KAYNAKÇA}

Almeqdad, Q., Al-Hamouri, F., Zghoul, R., Al-Rousan, A., \& Whitebread, D. (2016). Cross cultural indicators of independent learning in young children: A Jordanian case. The Spanish Journal of Psychology, 19. https://doi.org/10.1017/sjp.2016.35

Astarlar, F. (2019). Okul Öncesi Eğitime Devam Eden 4-6 Yaş Çocuklarının Öz Düzenleme Becerilerinin İzlenmesi (Yayınlanmamış yüksek lisans tezi). Pamukkale Üniversitesi, Denizli.

Baddeley, A. D., \& Hitch, G. J. (1974). Working memory. In G. A. Bower (Ed.), The psychology of learning and motivation: Advances in research and theory (Vol 8, pp. 4789). New York: Academic Press.

Bailey, R. \& Jones, S.M. (2019). An integrated model of regulation for applied settings. Clinical Child and Family Psychology Review, 22, 2-23. https://doi.org/10.1007/s10567-019$\underline{00288-\mathrm{y}}$

Bodrova, E. \& Leong, D. J. (2007). Tools of the mind: the Vygotskian approach to early childhood education (2nd ed.). Columbus, $\mathrm{OH}$ : Merrill/Prentice Hall.

Bodrova, E. \& Leong, D.J. (2005). Self Regulation: A Foundation for Early Learning. Principal, 85(1), 30-35.

Claussen, A.H., Robinson, L.R., Kawinski, J.W., Charania, S., Holbrook, J.R. So, M., Ghandour, R. Smith, C., Satterfield-Nash, A., Peacock, G. \& Boyle, C. (2020). Factors associated with self-regulation in a nationally representation sample of children ages 35 years United States, 2016. Maternal and Child Health Journal. https://doi.org/10.1007/s10995-020-03039-6

Cuevas, K., Rajan, V. \& Bryant, L. J. (2018). Emergence of executive function in infancy. (Eds. S. A. Wiebe \& J. Karbach), Executive function: Development across the life span (pp. 11-28). New York: Routledge.

Daggul, H. C. \& Işı1k Gürşımşek, A. (2019). Investigating pre-school children's self-regulation skills in terms of various variables in Northern Cyprus. Pegem Ĕ̈itim ve Ögretim Dergisi, 9(2), 491-522, http://dx.doi.org/10.14527/pegegog.2019.016

Eke, K. (2017). Okul Öncesi Dönemdeki Çocukların Öz Düzenleme Becerileri ile Anne-Baba Tutumları Arasındaki İlişkinin İncelenmesi, International Journal Of Eurasia Social Sciences, Vol: 8, Issue: 28, pp. (CCLXXIII-CCLXXXVII).

İvrendi, A. \& Erol, A. (2018, Mart). 4-6 yaş çocuklarına yönelik özdüzenleme becerileri ölçeği (ögretmen formu). Uluslararası Temel eğitim Kongresi -1'de sunulan bildiri, Uludağ Üniversitesi, Bursa.

Lenes, R., Gonzales, C.R., Storksen, I. \& McClelland, M.M. (2020). Children's self-regulation in Norway and the United States: the role of mother's education and child gender across cultural contexts. Frontiers in Psychology, 11:566208. DOI: 10.3389/fpsyg.2020.566208.

McClelland, M.M., Geldhof, G.J., Cameron, C.E. \& Wanless, S.B. (2015). Development and Self Regulation. R.M. Lerner (Ed.). Handbook of Child Psychology and Developmental Science (7th Edition), New York: John Wiley \& Sons, Inc.

McClelland, M.M. \& Cameron, C.E. (2012). Self-Regulation in Early Childhood: Improving Conceptual Clarity and Developing Ecologically Valid Measures, Child Development Perspectives, 6(2), 136-142.

McCoy, D. C. (2019). Measuring young children's executive function and self-regulation in classrooms and other real-world settings, Clinical Child and Family Psychology Review, 22, 63-74. 
Perry, N.E. (2019). Recognizing early childhood as a critical time for developing and supporting self regulation. Metacognition Learning, 14, 327-334. https://doi.org/10.1007/s11409-019-09213-8

Posner, M. I. \& Rothbart, M.K. (1998). Philosophical Transactions: Biological Sciences, Vol. 353, No. 1377, The Conscious Brain: Abnormal and Normal, pp. 1915-1927.

Saraç, S. \& Güleç, E. (2019). Yaşamın ilk yıllarında özdüzenlemenin gelişimi. H. Gülay Ogelman (Ed.), Gelişim bağlamında yaşamın ilk yılları: Erken çocukluk döneminde gelişim içinde (s. 379-402). Ankara: Eğiten Kitap.

Piotrowski, J.T., Lapierre, M.A. \& Linebarger, D.L. (2012). Investigating Correlates of Self Regulation in Early Childhood with a Representative Sample of English Speaking American Families, Journal of Child and Family Studies, 22, 423-436.

Raffaelli, M., Crockett L. J. \& Shen, Y. L. (2005). Developmental Stability and change in selfregulation from childhood to adolescence, The Journal of Genetic Psychology, 166 (1), 54-76, DOI: 10.3200/GNTP.166.1.54-76.

Shonkoff, J.D. (2000). Science, policy, and practice: three cultures in search of a shared mission. Child Development, 71(1):181-7 doi: 10.1111/1467-8624.00132

Storksen, I.,Ellingsen, I.T., Wanless, S.B. \& McClelland, M.M. (2015). The Influence of Parental Socioeconomic Background and Gender on Self-Regulation Among 5-YearOld Children in Norway. Early Education and Development, 26(5-6), 663-684, DOI:10.1080/10409289.2014.932238.

Tozduman Yaralı, K. \& Güngör Aytar, F.A. (2017). Okul öncesi dönem çocuklarının davranışlarının özdüzenleme becerileri yönünden incelenmesi. Mersin Üniversitesi Ĕ̈itim Fakültesi Dergisi, 13(3), 856-870. DOI: http://dx.doi.org/10.17860/mersinefd.291209

Tuzcuoğlu, N., Efe Azkeskin, K., İlçi Küsmüş, G. \& Cengiz, Ö. (2019). Okul öncesi dönem çocuklarının öz düzenleme becerileri ile benlik algıları arasındaki ilişkinin incelenmesi. IBAD Sosyal Bilimler Dergisi, 607-623. DOI: 10.21733/ibad.613920.

Ural, G., Gültekin Akduman, G. \& Şepitçi Sarıbaş, M. (2020). Okul öncesi dönem çocuklarının öz düzenleme becerilerinin bazı değişkenlere göre incelenmesi. EKEV Akademi Dergisi, 24(83), 323-342.

Veijalainen, J., Reunamo, J. \& Heikkila, M. (2019). Early gender differences in emotional expressions and self-regulation in settings of early childhood education and care. Early Child Development and Care. DOI: 10.1080/03004430.2019.1611045.

Widiastuti, A.A. (2017). Preschoolers self regulation and their early school success. Advances in Social Science, Education and Humanities Research (ASSEHR), 58, 39-43.

Zimmerman, B. J. (2002). Becoming a Self-Regulated Learner: An Overview, Theory Into Practice, 41(2), 64-70, DOI: 10.1207/s15430421tip4102_2 